\title{
TUBERCULOUS PAPILLITIS
}

\section{PAPILITIS TUBERCULOSA}

\author{
ASENSIO-SÁNCHEZ VM ${ }^{1}$, TORREBLANCA-AGÜERA B ${ }^{2}$, MARTÍNEZ-CALVO S ${ }^{2}$, CALVO MJ ${ }^{2}$, \\ RODRÍGUEZ R ${ }^{1}$
}

\begin{abstract}
Case report: We describe a 65-year-old asymptomatic woman with unilateral optic disc edema. Laboratory testing revealed a very marked positive PPD $(25 \mathrm{~mm})$ with dermatolysis. Anti-tuberculosis therapy resulted in complete resolution.

Discussion: Tuberculosis should be considered in the diagnosis of papillitis, even in asymptomatic patients (Arch Soc Esp Oftalmol 2006; 81: 37-40).
\end{abstract}

Key words: Ocular tuberculosis, papillitis, PPD.

\section{RESUMEN}

Caso clínico: Se describe una mujer de 65 años asintomática con un edema de papila unilateral. Las pruebas de laboratorio fueron negativas excepto un PPD de $25 \mathrm{~mm}$ con dermatolisis. El tratamiento antituberculoso llevó a una resolución del cuadro.

Discusión: La tuberculosis ocular se debe considerar en los pacientes con papilitis incluso siendo asintomáticos.

Palabras clave: Tuberculosis ocular, papilitis, PPD.

\section{INTRODUCTION}

Tuberculosis (TBC) is a declarable disease caused by mycobacterium tuberculosis, which mainly affects the lungs but can also involve any organ and/or tissue. The involvement of the eye can occur in the context of milliar tuberculosis (mainly choroideal infiltrates), but it can also appear in patients without evidence of active lung disease (1-4), as in this case.

\section{CASE REPORT}

A 65 year-old Ecuadorean woman without relevant personal or family history, who visited the

Received: 4/3/05. Accepted: 10/1/06

Hospital General. Medina del Campo. Valladolid. Spain.

$1 \mathrm{PhD}$. in Medicine.

2 Graduate in Medicine.

Correspondence:

V.M. Asensio Sánchez

Hospital General Servicio Castellano-Leonés de Salud

Servicio de Oftalmología

47010 Medina del Campo (Valladolid)

Spain

E-mail: vasensio@hmdc.sacyl.es 


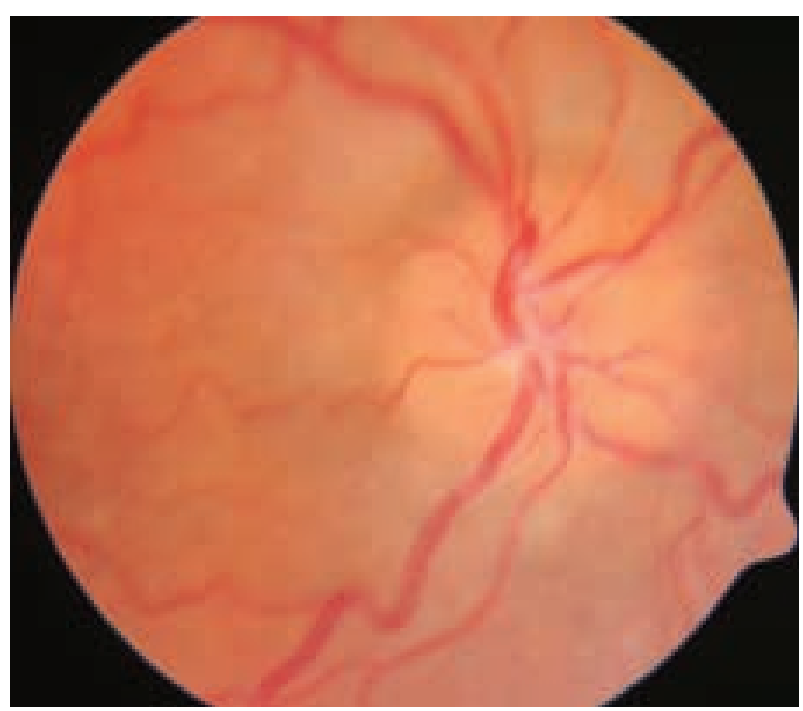

Fig. 1: Papillar edema and sub-retinian discrete exudate in the right eye.

external ophthalmology practice due to painless reduction of vision in the right eye (RE) with a 3-4 month evolution. Maximum visual acuity (VA) in the RE was 0.5 and in the left eye (LE) VA was 1. Extrinsic and intrinsic motility was normal. In the RE a papillar edema was appreciated with some sub-retinian exudate (fig. 1). Orbital and brain CAT and MRI, luetic serology, enzime converter of angiotensine, Lyme serology and thorax X-ray were negative. Systemic study via devices was not significant. In its first 24 hours, the man-toux or Tuberculosis Skin Test (PPD) already displayed a $25-\mathrm{mm}$ induration with areas exhibiting skin necrosis (fig.

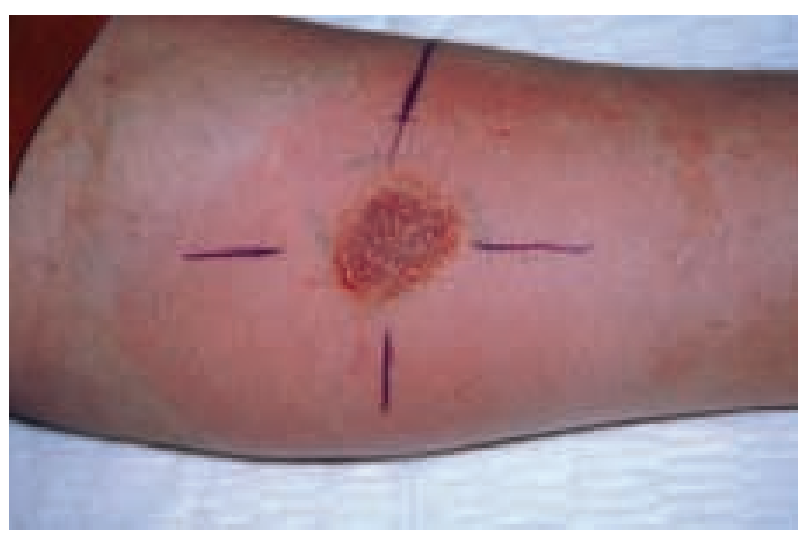

Fig. 2: Mantoux after 24 hours: $25 \mathrm{~mm}$ induration with necrosis.
2). The thorax X-ray was repeated with equally negative results. A cephallic liquid punction displayed an outgoing pressure of $16 \mathrm{~cm} \mathrm{H} 2 \mathrm{O}$ with normal biochemistry and negative culture. Electrophoresis of cephalic liquid did not reveal aligoclonal bands. Uroculture and expectoration culture were also negative for the growth of mycobacterium tuberculosis. As ocular tuberculosis was suspected, a test was made with $300 \mathrm{mg} /$ day of isoniacide for 3 weeks with subjective improvement in RE vision, although maximim vision remained at 0.5 . Isoniacide treatment was given $(300 \mathrm{mg})$ for 9 months together with Rifampin $600 \mathrm{mg}$ (9 months), pyrazinamide $15 \mathrm{mg} / \mathrm{kg}$ (2 months) and etambutol 15 $\mathrm{mg} / \mathrm{kg}$ (2 months).

One year after the first consultation, the visual acuity of the RE was 0.9 and its exploration gave normal results.

\section{DISCUSSION}

Tuberculosis is an infectious (acute or chronic) disease caused by mycobacterium tuberculosis, which involves mainly the lungs although it can target any organ or tissue $(1,3)$.

The incidence of ophthalmological expressions is of up to $2 \%$, although its assessment if considerably difficult $(1,3)$. Any eye tissue, excepting the lens, can be affected due to hematic dissemination, direct extension of the bacillus, as a response of a cellular reaction or as a Type 4 hyper-sensitivity $(2,3)$. The optic nerve is generally affected in the context of tubercular meningitis and mainly at the retro-bulbar level, the anterior area is usually affected secondary to choroiditis (4). Eye tuberculosis diagnosis is very difficult without evidence of a primary focus. Biopsy is usually reserved for seriously damaged tissue, and cephallic liquid puncture for M. tuberculosis in eye fluids is not standardized (4). In general, the TB diagnosis is endorsed by a positive thorax X-ray or by a positive PPD with induration (not edema) of $15 \mathrm{~mm}$ or more, associated to exposure antecedents. Stechschulte SU et al (4) described the case of a woman with TB which first appeared as neuroretinitis, with normal chest X-ray and necrotic $15 \mathrm{~mm}$ PPD. Even though the chest X-ray is normal in the described patient, the $25-\mathrm{mm}$ necrotic PPD and the positive response to antituberculose agents provided pointers towards diagnosing eye tuberculosis. 


\section{REFERENCES}

1. Rodríguez Ares T, Rojas Silva MV, Díaz-Llopis M. Enfermedades infecciosas. In: Sánchez Salorio M, Díaz-Llopis M, Benítez del Castillo Sánchez JM, Rodríguez Ares MT. Manifestaciones Oftalmológicas de las Enfermedades Sistémicas. Madrid: LXXVII Ponencia oficial de la sociedad española de oftalmología; 2001; 337-370.
2. Peiffer RL, Lewen RM, Yin H. Infectious diseases. Tuberculosis. In: Gold DH, Weingeist TA. The Eye In Systemic Disease. Philadelphia: Lippincott; 1990; 155-275.

3. Sheu SJ, Shyu JS, Chen LM, Chen YY, Chirn SC, Wang JS Ocular manifestations of tuberculosis. Ophthalmology 2001; 108: 1580-1585.

4. Stechschulte SU, Kim RY, Cunningham ET Jr. Tuberculous neuroretinitis. J Neuroophthalmol 1999; 19: 201-204. 